\title{
Efficacy of Foreign Direct Investment in India - An Evaluation
}

\author{
G. Shivagami \\ Research Scholar, Department of Economics, Bangalore University, Bangalore, Karnataka, India
}

\section{T. Rajendra Prasad}

Professor, Department of Economics, Bangalore University, Bangalore, Karnataka, India

\section{OPEN ACCESS}

Manuscript ID:

COM-2021-09023835

Volume: 9

Issue: 2

Month: April

Year: 2021

E-ISSN: 2582-6190

Received: 15.01.2021

Accepted: 25.03.2021

Published: 01.04.2021

Citation:

Shivagami, G., and

T. Rajendra Prasad.

"Efficacy of Foreign Direct

Investment in India - An

Evaluation." ComFin

Research, vol. 9, no. 2,

2021, pp. 38-46.

DOI:

https://doi.org/10.34293/

commerce.v9i2.3835

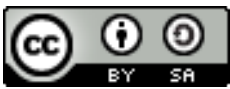

This work is licensed under a Creative Commons Attribution-ShareAlike 4.0 International License

\begin{abstract}
Foreign investment plays a noteworthy role in all walks of development. Foreign Direct Investment bridges the gap between saving and investment. In the process of economic development, foreign capital helps to cover the domestic saving constraint and provide access to the superior technology that promotes efficiency and productivity of the existing production capacity and generate new production opportunity. The perceptible growth of India's GDP, particularly in the past few decades has lifted millions of people from sever poverty on the one hand and made the country a conducive ground for foreign direct investment on the other hand. A recent UNCTAD survey projected India as the second most important FDI destination after China for transnational corporations during 2010-2015. Services, telecommunication, construction activities, computer software \& hardware and automobile are major sectors, which attracted higher inflows of FDI in India. Few nations such as Singapore, Mauritius, the US, and the UK were among the leading suppliers of FDI in India. This paper intends to examine the degree of global countries' participation, the sector-wise inflow of foreign capital and the recent initiatives of the government policy towards foreign direct investment.
\end{abstract}

Keywords: FDI, Capital, Industrial sector, Growth, Development, Infrastructure, Productivity

\section{Introduction}

Foreign investment plays a noteworthy role in all walks of development; it bridges the gap between saving and investment. In the process of economic development, foreign capital helps to cover the domestic saving constraint and provide access to the superior technology that promotes efficiency and productivity of the existing production capacity and generate new production opportunity. The perceptible growth of India's GDP, particularly in the past few last decades has lifted millions of people from acute poverty and made the country a favorable ground for foreign direct investment. In its recent report, UNCTAD uttered that India is the second most important FDI destination after China for international investors during2010-2015. Services, telecommunication, construction activities, computer software $\&$ hardware and automobile are major sectors that attracted higher inflows of FDI in India. Few nations such as Singapore, Mauritius, the US, and the UK were among the leading suppliers of FDI in India. In this connection, the present paper intends to examine the inflow of foreign capital to different sectors of the economy, particularly to assess foreign capital flows in the industrial arena.

\section{Review of Literature}

Rekha Shrivastava, et al., (2016), A study of foreign direct investment in the Indian telecommunication industry. The key objective of the research is to find out the status of the telecom sector in India. This study was conducted with the 
support of secondary data for the period from 20002015. The speedy growth of the Indian economy coupled with the stable economic outlook, bulky market potential, big talent pool, and low labor cost attracted the attention of global investors and became a suitable ground for foreign investment.

Areej Aftab Siddiqui and Shahid Ahmed (2017) study the impact of FDI on the sectoral enhancement of the Indian economy. The prime motto of the study is to examine the cause and consequences of FDI on growth at the sectoral level, using secondary dataset collected for the period 2000 to 2014 . The main suggestion of the study is steppes should be taken for attracting FDI in export-oriented sectors so that higher growth could be achieved for this sector and thus for the Indian economy at the aggregate level.

Bose (2012), in his wide-ranging research, examined the trend of FDI in Asia's emerging economies using time-series data collected from different data sources. As part of this research effort, the author captured both positive and negative effects of foreign direct investment through the means of descriptive statistics and explorative research.

According to Basu et al., (2007), the new economic policy introduced in 1991 made the nation very vibrant in economic activities and attracting foreign investment further for the past few years. Further, the outcome of his research revealed that the $R \& D$ activities of the nations are the most significant determinant of foreign direct investment.

Sahoo and Mathiyazhagm (2003), in their multidimensional research, scrutinized the probable effects of foreign direct investment on both GDP and export. Their estimated result demonstrated a positive correlation among FDI, export and GDP over the study period. Country to above, the empirical evidence of Hanson reported that there is a weak sign for the positive mark of FDI on the host countries. While, Jha, in his Indian scheme of thingsexamined the recent trends of FDI inflow to India. Interestingly, he has highlighted the new mechanism implemented by the government for calculating the FDI figures, which is globally recognized.

Sahoo et al. (2002), has reported that the inflow of FDI to the transition countries seems to be a chief source of not only capital but also technological upgradation to those nations.
Srivastava, (2003), in his academic writings, described that some hurdles such as infrastructural bottleneck, centralized decision-making mechanism, low labor cost exit barriers, limited export processing zones, and high import tariff make the nation as an unattractive destination for foreign investment.

Rajalakshmi K and Ramachandran F (2011) studied the effects of FDI flow in the automobile sector of India, with a special focus on the passenger car. The authors have considered the total amount of foreign direct investment received by the automobile sector in general and passenger cars in particular to achieve their goal. For the purpose of estimating the impact of FDI in the above-mentioned sector, particularly during the post-liberalization period, they have applied some suitable models such as compound model, ARIMA, linear model, and coefficient estimation. The author has also examined the trend and composition of FDI flow and the effect of FDI on economic growth. The author has also identified the problems faced by India in the FDI growth of the automobile sector through suggestions of policy implications.

Bahar. S.N and B.V Khandare (2012) have attempted to measure the structure of FDI flow in the Indian context during the post-reform period. The core objective of the present research is to asserting the structural change in the flow of FDI and changes in the direction of flow during the above mentioned period. To do the same, the authors have applied two strategies such as (i) sectoral flow of foreign direct investment and (ii) country-wise flow of the same up to 2010 to India. At the final stage of the research, the authors have computed the eventual benefits of the flow of FDI on the economic growth of the nation.

\section{Objectives of the Study}

- To assess the global participation of foreign investment in the Indian economy in recent years.

- To examine the foreign capital inflow into the Indian Industrial sectors in general and Telecom Sector in particular.

- To study the Indian Government policy towards foreign direct investment in India in the contemporary scenario. 


\section{Methodology}

To execute the study on the inflow of Foreign Capital in the Indian Economy and particularly on various industrial sectors, secondary sources were collected from leading books, journals, magazines, annual reports of Reserve Bank of India, Government of India's recent publication of Economic Survey, TRAI, and other documents. Apart from the abovepublished sources, the stud also explores the related articles from the websites.
Global Participation in Foreign Direct Investment

As part of the developmental agenda, the government of India has been introducing a good number of programs to invite global investor and to attract a huge volume of foreign direct investment. A benchmark program was introduced in 1991 in the form of a new economic policy. Efficiency enhancement and increase in export volume are the two major objectives of foreign direct investment in general and developing countries.

Table 1: Top Ten Countries Foreign Direct Investment in India (Amount in US \$ Million)

\begin{tabular}{|c|c|c|c|c|c|c|}
\hline Rank & Country & $\begin{array}{c}\text { 2014-15 } \\
\text { (April-March) }\end{array}$ & $\begin{array}{c}\text { 2015-16 } \\
\text { (April-March) }\end{array}$ & $\begin{array}{c}\text { 2015-16 } \\
\text { (April-Sept) }\end{array}$ & $\begin{array}{l}\text { Cumulative Inflows } \\
\text { (April 00-Sept 16) }\end{array}$ & $\begin{array}{l}\% \text { to total } \\
\text { inflows }\end{array}$ \\
\hline 1 & Mauritius & 9,030 & 8,355 & 5850 & 10,1760 & 33 \\
\hline 2 & Singapore & 6742 & 13,692 & 4680 & 50,560 & 16 \\
\hline 3 & U.K & 1447 & 898 & 964 & 24,072 & 8 \\
\hline 4 & Japan & 2084 & 2614 & 2795 & 23,760 & 8 \\
\hline 5 & U.S.A & 1824 & 4192 & 1437 & 19,380 & 6 \\
\hline 6 & Netherland & 3436 & 2643 & 1615 & 18,929 & 6 \\
\hline 7 & Germany & 1125 & 986 & 588 & 9217 & 3 \\
\hline 8 & Cyprus & 598 & 508 & 381 & 8933 & 3 \\
\hline 9 & France & 635 & 598 & 183 & 5294 & 2 \\
\hline 10 & U.A.E & 367 & 985 & 355 & 4385 & 1 \\
\hline \multicolumn{2}{|c|}{ Total } & 30,931 & 40,001 & 21,624 & 31,0258 & - \\
\hline
\end{tabular}

Source: FDI statistics

Table 1 shows that the major share of FDI (which accounts for $86 \%$ ) inflows is streamed from these ten countries; at the same time, the remaining nations of the world have contributed $14 \%$ of the total flow of foreign direct investment. It also illustrates a huge amount - 22423 US \$ millions of FDI was received during 2012-13 from 113 countries' NRI members. Interestingly, during this period, India's overseas outlook had significantly increased. As a result, the confidence level of the global visitors in India has gradually improved. Singapore, with 33 per cent in the total flow, holds second place in terms of contributing FDI to India. Simultaneously, some developed countries such as the UK, Japan and USA occupied subsequent places with $8 \%, 8 \%$ and $6 \%$ respectively. Even the Netherland is in sixth place with a $6 \%$ contribution in the total inflow to India. At the same time, other nations such as Germany, Cyprus and France have contributed 3\%, 3\%, and $2 \%$ respectively, while UAE contributed plenty of just $1 \%$ in the total foreign capital.

It is transparent from table 1 , that the nations such as Singapore and Mauritius contributed about 50\% of total FDI to India. The major reasons cited for the above-mentioned trend are that they suggested tailormade resolutions in offshore banking and sliced the tax rate and robust privacy. In addition to them, these nations enacted the Double Tax Avoidance Agreement (DATA) through which there is no tax burden in India on the profit made by the investor of those nations. Rather, the investors of that nation pay the tax in the respective country; this rate is far below the tax slabs of India.

Mauritius is the appropriate route through which a good amount of FDI has been received by India. One way of looking at things could be the possible role of round-tripping for the large share of inflows from Mauritius. The mode of reinvesting our money through FDI by different nations is denoted as Round tripping, i.e. at the first stage, money travels 
to Mauritius from India and in the second stage returns back to India as FDI. In 2015-16 there were anxieties on the outcome of GAAR and possible renegotiation of the tax avoidance treaty. Hence, the flow of FDI from Mauritius dipped. GARR attempts to check tax avoidance by the stakeholder investors stashing their money through tax anchorages. The India-Mauritius DTAA has been abandoned, and the capital investment entering from Mauritius is subject to the capital gain tax after April 1, 2017. Further, as per the new law, any entity treated as a Mauritius entity has to spend at least Mauritius $\$ 15$ lakh in Mauritius annually. But still, the cancellation of DTAA has not at a larger scale as the people assured that the government would postpone it further.

Table 2: Top 10 FDI Receiving Sectors: An Analysis Sector-wise Foreign Direct Investment in India (amount in US \$ million)

\begin{tabular}{|c|l|c|c|c|c|c|}
\hline Rank Sector & $\begin{array}{c}\mathbf{2 0 1 4 - 1 5} \\
\text { April- } \\
\text { March) }\end{array}$ & $\begin{array}{c}\mathbf{2 0 1 5 - 1 6} \\
\text { (April- } \\
\text { March) }\end{array}$ & $\begin{array}{c}\mathbf{2 0 1 6 - 1 7} \\
\text { (April- } \\
\text { Sept) }\end{array}$ & $\begin{array}{c}\text { Cumulative } \\
\text { Inflows (April } \\
\text { 00-Sept 16) }\end{array}$ & $\begin{array}{c}\text { \% to } \\
\text { total } \\
\text { inflows }\end{array}$ \\
\hline 1 & Service sector & 4443 & 6889 & 5288 & 56080 & 10 \\
\hline 2 & Construction Development Township Housing & 769 & 113 & 62 & 24250 & 8 \\
\hline 3 & Computer software \& hardware & 2296 & 5904 & 1032 & 22050 & 7 \\
\hline 4 & Telecommunication & 2895 & 1324 & 2787 & 21169 & 7 \\
\hline 5 & Automobile industry & 2726 & 2527 & 729 & 15793 & 5 \\
\hline 6 & Drugs \& pharmaceuticals & 1498 & 754 & 641 & 14490 & 5 \\
\hline 7 & Trading & 2728 & 3854 & 1482 & 13354 & 4 \\
\hline 8 & Chemicals (other than fertilizers) & 763 & 1470 & 532 & 12433 & 4 \\
\hline 9 & Power & 707 & 869 & 559 & 11035 & 4 \\
\hline 10 & Hotel \& Tourism & 777 & 1333 & 523 & 9750 & 3 \\
\hline
\end{tabular}

Source: DIPP fact sheet on FDI

The statistic presented in table: 2 describes the inflow of FDI in the top ten sectors from April 2000 to Sep 2016. The services sector has encompassed by the sub-sectors such as Non-Financial/ Business, Outsourcing, R \& D, Financial, Banking, Insurance, Courier, Tech. It is visible from the table that it is the service sector, which attracted a sizable amount of investment and held the first place. The mention that should be made here is that this is a key sector of the nation in augmenting the GDP. The service sector is the dominant sector of India's GDP and attracts a huge volume of foreign investment. In addition to that, it augments the volume of exports and generates a massive number of employment opportunities. It should be mentioned here is that though the construction sector was in the second position in attracting the FDI, there is a downturn trend in the recent past as a result of time delay in the acquisition of land. As a reacting mechanism, the government has announced the minimum built-up law and capital requirement strategy after realizing a radical fall in the flow of FDI. But, to increase the flow, the government of India has magnified the investment, which is flowing from foreign countries, and simplified the channel. It was also categorical that each phase of the project was a separate one for FDI policy. With a line's shave, the computer software industry demonstrated as a rapidly emerging sector in Indian. Remarkable, the speedy inflow of FDI had been found from 2007-08 in the Computer Software and Hardware Industry. The availability of skilled labor force, growing market, regulatory frames, and the emergence of software technology parks are the driving forces for the increase of FDI inflow in India. Further evidence revealed that the innovative reforms introduced in the IT sector through the Make in India program and favorable policy environment. The government of India is also targeting zero imports by 2020 hence, introduced several packages to promote the service-based economy of the nation.

The inflows ofFDI towards the telecommunication sector do not present a cozy picture as it has decreased 
from the US\$ 2895 million in the year 2015-16 to US\$ 1324 million in 2019. This was observed particularly after the huge investment earmarked by the Vodafone company. Presently, this subsector has marched towards 5G. The digital India initiative was also one of the driving forces to this industry; hence, in the recent past, this industry is assumed to be a higher growth industry in India. In the recent past, the flow of FDI to the automobile industry of the nation has witnessed immense growth. The car's increase on other vehicles can be attributed to the substantial increase in disposable income, liberalized financial system including easy repayment option. The substantial increase in foreign car manufacturers also facilitated domestic consumers to choose best.

The introduction of the automotive mission plan in 2006-16 was the major initiative of the Indian government to make this nation into the global automotive hub. The major motto of this plan was to make our nation turn out to be the conducive ground for the production of automobiles and their parts. Hence, it was targeted to reach US\$ 145 billion and generate around 25 million employments by 2016 . Thanks to the government's initiatives and support from foreign companies, the pharmaceutical industry has experienced generous growth. The existing strengths, such as a sturdy production base, skilled labor, and huge population, are attracting foreign investors to pump their money into India. FDI into India. The outsourcing of the maximum portion of the production of pharmaceuticals and lackadaisical level of investment in this sector are attributed to the rigid labor laws and weak patent regime. Further, the Indian government has liberalized pharmaceutical related policies for the purpose of attracting a huge amount of FDI.

\section{Foreign Direct Investment in Telecom Sector}

All over the world, telecommunication has been considered as an influential equipment to achieve poverty alleviation through the empowerment of society. The telecommunication sector is one of the key enablers for achieving 'inclusive and sustainable by reducing unemployment, poverty, inequality, and disparity. Further, the role of this sector is commendable in generating employment opportunities and protecting the vulnerable section of society. With the perceptible growth in the wireless sector, this component has emerged as a major driver of growth in the Indian context for the past few decades. The diffusion of broadband and the internet has also improved markedly. As a part of the development scheme, the Indian government has permitted a project to create the NOFN - National Optical Fiber Network for connecting 2.5 lakh Gram Panchayats with support with the financial support given by the Universal Service Obligation Fund (USOF). The proposed National Telecom Policy, under finalization with the approval of different stakeholders, is an upward step for achieving sustainable growth shortly.

In the Indian context, the telecommunication sector has sustained appreciable growth for the past few years. Indian telecom network has 1195.24 million connections at the end of September 2019. Further, it has emerged as the second-largest network holder in the world after China. The one billion marks also appear to be achievable. The total number of subscribers to the internet and broadband has increased significantly to 687.62. The future progress of telecommunication in our country is very encouraging as operators have started rolling out the wireless broadband networks in the country. Soon, the services are expected to be available in the entire country. The present status of the telecom sector are as follows:

- The Indian telecom market is one of the fastestgrowing markets in the world.

- With its 1195.24 million Telephone connections, it is the second-largest network.

- In that 677.95 million urban subscribers and 517.29 million rural subscribers.

- Telephones are $96.47 \%$ of the total phones. The share of the private sector in total telephones is $88.81 \%$.

- While rural Tele-density is at $57.28 \%$, increasing in the fastest rate, broadband connections increased to 687.62 million at the end of September 2019.

- Perceptible improvement in Telecom subscribers: Currently, India holds the second position globally in terms of the telecommunication market and placed in the third position concerning the total number of internet users during FY 09-19. The 
statistical evidence describes that the telephone subscriber of India has1,195.24 million with an annual compound growth rate of 19.5 percent.

- Wireless segment governs the market: The total number of telephone subscribers of this nation has reached 1,173.75 million at the end of 2019 . It is the wireless segment, which dominates the market with a subscription rate of 97.46 percent.

\section{Figure 1}

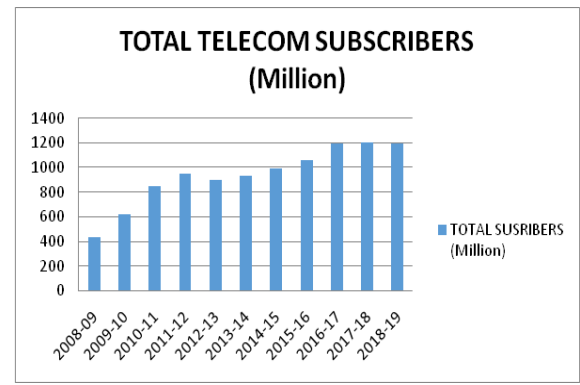

Source: Annual Report of TRAI

The government of India had enacted the liberal economic policy in the year 1991. The effective mover of the government through an open door system has increased the rate of competition in the goods market, particularly in cellular services. This trend attracted the attention of foreign investors significantly. The foreign ownership in the telecom sector has come in with the tender introduced in 1994, which facilitated private licensing and cellular services. In the tender rule, it is specified that only the companies registered in India could quote.

Nevertheless, it has permitted the companies to pursue joint ventures with approximately $49 \%$ of the foreign capital. It is to be cited here that the license condition too highlighted this cap for foreign capital, but this not focusing on direct capital, which is emphasizing the total foreign equity. As a part of the developmental agenda, the government of India has further liberalized FDI related policy for the benefit of the service sector. These include liberalizing the policy on foreign investment for companies operating in the broadcasting sector, like increasing the foreign investment limit from 49 percent to 74 percent in teleports (setting up up-linking HUBs/ teleports) and direct to home (DTH) and cable networks and permitting foreign investment (FI) up to 74 percent in mobile TV; permitting foreign airlines to make foreign investment and up to 49 percent in scheduled and nonscheduled air transport services. Companies such as BPL, Idea, Hutchison, Bharti, and Spice have come into prominent places due to the government's decision to increase the sealing of FDI limit to telecom service providers. Interestingly, the investors, who are the beneficiaries of increasing FDI limits, are assumed that both expansion and penetration of this sector is possible with the support of the huge volume of FDI.

Further, they believe that the increase in the FDI limit will remove the hurdles emerging in the telecom sectors. Right from the beginning, the private operators of this company had been expecting to lift the slap of the FDI. Even the global level leading agencies such as the World Bank and IMF had suggested reducing the restriction of FDI limit. Further, the operators of cellular and also different types of foreign financial institutions are expected to increase the sealing of foreign ownership. Despite all these efforts, the government of India had resisted such moves, primarily on security considerations, until 2013.

To fulfill the deficit of the fund-starved industries, the government of India has approved the 100 per cent FDI in the telecom sector on1st August 2013. More specifically, it is decided to increase the FDI cap from 74 per cent to 100 percent, of which around 49 percent by way of automatic route. The rationale behind the cap's increase is mainly due to lower the financial burden and get fresh financial support from different parts of the world. The initiative of the Indian government has created a space for foreign partners to become owners of business activities. Added strength is that the industry analysts trust that the initiatives of the government will attract atleast US $\$ 10$ billion shortly. The decision to control another organization wrongly approved by entities.

It is generally accepted that Telecom is one of the capital-intensive sectors of the nation. The Telecom companies of the nation have got the special channel to access the financial resources from the foreign capital market due to the positive approach of the Indian government in approving the FDI. Hence, those companies can serve the hinterland and bringing affordable telecom services. As a result of the unleashed rules for the inflow of foreign direct investment, the telecom sector received sufficient 
funds for its development and flexibility for its economic operations. The perceptible improvement in capital level of the telecom sector would facilitate industrialists in this sector to achieve appreciable growth through infrastructural development.

Further, the degree of mergers and acquisitions in the telecom sector can be increased by increasing the limit of foreign capital. Hence, it can be mentioned that the initiatives of the government towards a liberal policy on FDI flow would result in capital deepening in the telecom sector shortly.

Table 3: FDI in Indian Telecom Sector during 2009-10 to 2018-19

\begin{tabular}{|c|c|c|c|}
\hline Year & $\begin{array}{c}\text { FDI inflow } \\
\text { Rs (crores) }\end{array}$ & $\begin{array}{c}\text { FDI inflow } \\
\text { US\$ (million) }\end{array}$ & Percentage \\
\hline $2009-10$ & 12338 & 2554 & $8 \%$ \\
\hline $2010-11$ & 7546 & 1665 & $8 \%$ \\
\hline $2011-12$ & 9012 & 1997 & $7 \%$ \\
\hline $2012-13$ & 1654 & 304 & $7 \%$ \\
\hline $2013-14$ & 7987 & 1307 & $7 \%$ \\
\hline $2014-15$ & 17372 & 2895 & $7 \%$ \\
\hline $2015-16$ & 8637 & 1324 & $7 \%$ \\
\hline $2016-17$ & 37435 & 5564 & $6 \%$ \\
\hline $2017-18$ & 39748 & 6212 & $8 \%$ \\
\hline $2018-19$ & 18337 & 2668 & $8 \%$ \\
\hline
\end{tabular}

Source: www.dot.in

\section{Recent Government Policy towards FDI}

The favorable policy regime of the Indian government towards the development of business has supported to the inflow of foreign direct investment. There was a substantial improvement in for inflow of FDI to the nation. Further efforts of the Indian government, such as unleashed FDI rule in some of the sub-sectors such as power exchange, PSU oil refineries, stock exchange, and defense are also reinforced the inflow of FDI.

\section{Market Size}

- As per the statistics given by the department for the promotion of industry and International Trade (DPI), the total volume of the FDI equity inflows between 2000 and 2019 was US\$ $\$ 446.11$ billion in the Indian stock market. This trend explicates that the recent efforts of the government of India are yielding results.
- The inflow of FDIin India has reached the US \$ 26.09 billion during April Sep 2019. Further, the available statistics revealed that for quarter two 2019-20; the services sector attracted the highest FDI equity inflow of the US $\$ 4.45$ billion followed by the telecommunications sector the US \$4.28 billion, computer, software, and hardware- the US \$ 4.02 billion, and trading the US \$ 2.14 billion.

- India has received a maximum quantity of FDI inflow from Singapore during the second quarter of the year to the worth of US\$ 8.01 billion. Further, the flow was appreciable from few more countries, such as from Mauritius US\$ 6.36 billion, from the Netherlands, US \$2.32 billion. Simultaneously, two advanced nations such as the USA and Japan have contributed the US \$ 2.15 billion, and US $\$ 1.78$ billion respectively.

\section{Recent Development}

Recent announcements concerning FDI as follows:

- Amazon India, in Jan 2020, came forward to digitalizing the small and medium scale enterprises and create one billion jobs in 2025 in the nation with the investment allocation of US \$ 1 billion.

- To double-up the market expansion, in Jan 2020, Mastercarddecided to invest the US \$ 1 billion in India over the next five years.

- The French oil and gas giant Total SA has acquired in Oct 2019 approximately 37.4 per cent of the stake in Adani Gas ltd for US\$ 810 million, which created a huge junk of foreign investment to the Indian economy, particularly in the CityGas Distribution(CGD) sector.

- In Aug 2019, Reliance Industries (RIL) announced one of Indian biggest FDI deals, as Saudi Aramco will buy a 20 percent stake in Reliance Oil to Chemicals (OTC) businesses at an enterprise value of US \$ 75 billion.

- In Oct 2018, VM Ware, a leading software innovating enterprise of the US announced an investment of the US \$ 2 billion in India between 2023.

- In Aug 2018, Bharthi Airtel received the government of India for the sale of 20 percent in 
the DTH arm to an America-based private equity from Warburg Pincus, for around \$ 350 million.

- The approval of 100 percent FDI in telecommunication coupled with the merger with Vodafone, it becomes a largest operator in India

- By investing 77 percent in the total value of Flipkart, Walmart became the leading participant.

- Further, as a part of the developmental strategy, IDEA has announced to invest Rs 4000 crore at Maharashtra for the purpose of constructing the Multiformal stores and experience center.

\section{Government Initiatives}

- The government of India in Aug 2019 approved the 100 percent FDI inflow to the coal mining industry (as well as in developing allied manufacture like washeries) through the automatic route.

- The government of India has generously liberalized the flow of FDI in vibrant sectors such as insurance, aviation and media, in consultation with stakeholders.

- In the case of insurance intermediaries also 100 percent FDI is permitted.

- The government of India, in 2019, increased the Draft National E-commerce policy, which encounters FDI in the Market place model of e-commerce. Further, for the purpose of facilitating this sector and for the benefit of all participants, the FDI policy for E-commerce has been created.

- The National digital communication policy, announced in 2018 was supported to increase the level of FDI in the telecommunication sector, and it is projected to receive US\$ 100 billion by 2022 .

- The government of India allowed up to 49 per cent of investment in Air India by investors of foreign airlines in 2018. At the same time, it described that the investment (both direct and indirect) should not increase 49 percent.

- Further, the government of India has announced that there is no government approval required for FDI real estate banking services, that too up to 100 percent.

- To increase the quantum of FDI defense and facilitate the stakeholders, the government of India discussed with the stakeholders to increase the slap from $49 \%$ to $51 \%$. Through this, it is decided to boost the make in India initiative and to generate more employment opportunities.

\section{Conclusion}

Foreign direct investment has a noteworthy role in the growth and development of the Indian economy through the expansion of sub-sectors and the creation of more employment opportunities. The substantial inflow of foreign direct investment in the general and service sector in particular from 2000 facilitated the Indian economy to achieve the targeted growth and engage the skilled and unskilled labors. Other sub-sectors, which attracted an appreciable amount of foreign direct investment includes Drugs \& Pharmaceuticals, software and hardware, and computer. Though the above-mentioned sectors experienced a substantial improvement in terms of observing the foreign direct investment, the remaining sectors in the Indian economy failed to attract the foreign direct investment for their progress. Foreign direct investment performs as a vehicle to attain the long-run sustainable growth as this is not only a source to bridge the dearth of capital but also increase in the competitive spirit of the domestic industries through imported machines and technology, increase in employment opportunities, improved human capital, and productivity. Hence, it is possible to receive a huge volume of foreign direct investment even in the future as the World Investment report (2010) rightly pointed out that in the global arena, India has emerged as the fifth-largest recipient and second-largest among the developing worlds in terms of receiving foreign direct investment.

\section{References}

Agarwal, R.N. "Foreign Portfolio Investment in Some Developing Countries: A Study of Determinants and Macroeconomic Impact." Indian Economic Review, vol. 32, no. 2, 1997, pp. 217-229.

Aggarwal, Shalini, et al. "Foreign Direct Investment in India." International Journal of Computational Engineering \& Management, vol. 15, no. 5, 2012, pp. 93-105.

Annual Report 2009-10. Department of Telecommunications, Government of India. 
Azhar, Syed, and K.N. Marimuthu. "An Overview of Foreign Direct Investment in India." International Journal of Multidisciplinary Management Studies, vol. 2, no. 1, 2012.

Balasubramanyam, V.N., and Vidya Mahambre. "Foreign Direct Investment in India." Lancaster University Management School Working Paper No. 2003/001, 2002.

Bhavya, Malhotra. "Foreign Direct Investment: Impact on Indian Economy." Global Journal of Business Management and Information Technology, vol. 4, no. 1, 2014, pp. 17-23.

Bose, Tarun Kanti. "Advantages and Disadvantages of FDI in China and India." International Business Research, vol. 5, 2012, pp. 164-174.

Chakrabarthi, Rajesh. "FII Flows to India: Nature and cases." Money and Finance, vol. 2, no. 7, 2001, pp. 61-81.

Chatterjee, Sumana. An Economics Analysis of Foreign Direct Investment in India. Maharaja Sayajirao University of Baroda, 2009.

Devajit, Mahanta. "Impact of Foreign Direct Investment on Indian Economy." Research Journal of Management Sciences, vol. 1, no. 2, 2012, pp. 29-31.

Gopika, G.G. "Foreign Direct Investment Policies in the Liberalized Telecom Sector of India - A Review." International Journal of Business and Management Invention, vol. 3, no. 3, 2014, pp. 1-8.

Gupta, A.K., and Amit Kumar Sharma. "Benefits of FDI in Telecom Sector." Professional Panorama, pp. 48-66.

Gupta, K.L., and Harvinder Kaur. New Indian Economy and Reforms. Deep and Deep publications, 2005.

Kumar, Nagesh, and Jaya Prakash Pradhan. "Foreign Direct Investment, Externalities and Economics Growth in Developing countries: Some Empirical Explorations and Implications for WTO Negotiations on investment." RIS Discussion Paper 27, 2002.

Kumar, Pradeep. "FDI in India and its Impact - A Critical Evaluation." VRSD International Journal of Business \& Management Research, vol. 1, no. 3, 2011, pp. 185-196.

Mahajan, D. "FDI in India not as per her Potential." The Economic Challenger, vol. 41, no. 11, 2008, pp. 59-63.

Mohamed Idris, P. "FDI Inflows in India." Shanlax International Journal of Arts, Science and Humanities, vol. 3, no. 1, 2015, pp. 130-133.

Shrivastava, Rekha, et al. "A Study of Foreign Direct Investment in the Indian Telecommunication Industry." International Journal of Commerce and Management Research, vol. 2, no. 12, 2016, pp. 30-34.

Siddiqui, Areej Aftab, and Shahid Ahmed. "Impact of Foreign Direct Investment on Sectoral Growth of Indian Economy." International Journal of Economics and Financial Issues, vol. 7, no. 3, 2017, pp. 477-488.

Syed Ibrahim, M., and A. Muthusamy. "Role of FDI in India's Economic Development - An Analysis." Journal of International Relations and Foreign Policy, vol. 2, 2014, pp. 101-113.

Teli, R.B. "A Critical Analysis of Foreign Direct Investment Inflows in India." Procedia Social and Behavioral Sciences, vol. 133, 2014, pp. 447-455.

Tigari, Harish. "An Analytical Study on Foreign Direct Investment in Indian Perspective." Shanlax International Journal of Economics, vol. 6, no. 1, 2017, pp. 50-55.

Yadav, Kapil, et al. "Impact of Technological Changes in Telecom Sector in India." Indian Journal of Science and Technology, vol. 8, 2015, pp. 194-199.

\section{Author Details}

Mrs. G. Shivagami, Research Scholar, Department of Economics, Bangalore University, Bangalore, Karnataka, India

T. Rajendra Prasad, Professor, Department of Economics, Bangalore University, Bangalore, Karnataka, India, Email ID: trprasadbub@gmail.com 